\title{
Contaminants in local alcoholic beverages: zinc and manganese contamination
}

\author{
S. Y. GAZUWA *, J. D. DABAK and G. A. UBOM \\ Department of Biochemistry, Faculty of Medical Sciences, University of Jos, PMB 2084, Jos. \\ "Corresponding Author, E-mail: sygazuwa@yahoo.com
}

\begin{abstract}
The extent of leaching of zinc ( $\mathrm{Zn})$ and manganese $(\mathrm{Mn})$ from the vessels used during the preparation of two local alcoholic drinks, Pito and Burukutu has been assessed. Leaching of these metals during the four phases of fermentation was monitored by determining the levels of the metals in each phase using atomic absorption spectrophotometric technique; in each complete fermentation protocol, metallic or clay container was used. Contamination appeared to be due to the fermentation process, container used or a combination of the two. Comparatively, there was increase in the levels of these metals from the initial to the final phase of fermentation for both types of vessels; in each case, appropriate controls were used. Compared to control values, the average increase in the level of zinc in Burukutu and Pito for metallic and clay containers is 343\%; $325 \%$ and 295\%; $252 \%$ respectively; whereas for manganese the increases are $815 \%$; $1438 \%$ and $1292 \%$; $1150 \%$ in that order. The differences in the levels of these metals among the phases in each of the drinks were significant $(\mathrm{p}<0.05)$.

(C) 2008 International Formulae Group. All rights reserved.
\end{abstract}

Keywords: Fermentation, Containers, Clay, Metallic, Burukutu, Pito.

\section{INTRODUCTION}

Contaminants have been reported to be present in foods including local alcoholic drinks (Okoye and Ekpengyong, 1984; Obasi et al., 1987; Gazuwa et al., 2006). These contaminants could be organic or inorganic elements such as copper $(\mathrm{Cu})$, iron $(\mathrm{Fe})$, manganese $(\mathrm{Mn})$ and zinc $(\mathrm{Zn})$. Zinc is a component of over 300 metalloenzymes and also boosts the immune and reproductive systems, shortens duration of cold, optimises sense of taste and smell (Okoye, 1992; Mossad et al., 1996; Mackmin et al., 1998; Butta et al., 1992). On the other hand, manganese $(\mathrm{Mn})$ is essential for healthy bone and cartilage formation, as cofactor of hexokinase, glucokinase, activates superoxide dismutase. It is involved in protein metabolism, building and degradation of nucleic acids, biogenic amine metabolism which is crucial in nerve impulse transmission (Murray et al., 1996).

Notwithstanding these crucial functions however, zinc toxicity has been reported to impair immune function; inhibit the absorption of copper, calcium, iron and magnesium and promote folate deficiency (Fosmire, 1990; Sandstead, 1995; Dawson et al., 1990; Spencer et al., 1994; Bennett et al., 1997). Razak (2006) reported that zinc enters the milieu in a number of ways both natural and artificial through human activities such as mining, burning of coal, steel production and the burning of waste.

On the other hand, Mn has significant neurological, reproductive and pulmonary toxicity when absorbed and distributed in critical tissues and organs such as liver, pancreas and kidneys in excessive amounts (Finley, 1999; Krieger et al., 1995).

The study area is famous for mining activities and therefore numerous mining ponds, streams, and rivers abound in the environment from where underprivileged local brewers of native beers obtain water for brewing local alcoholic drinks. In this work 
however, metallic and clay containers were purchased from the market in which the drinks were prepared in the laboratory under controlled conditions using standard method (Okoh, 1998) to monitor the interrelationship between contaminations and brewing process, as well as type of container used. The ease with which the likely presence of contaminants in native alcoholic drinks is overlooked and therefore not implicated in disease conditions among drinkers, ascribing them solely to ethyl alcohol, necessitated this work. Although the presence of contaminants in foods has been reported, whether contamination of these alcoholic drinks by zinc and manganese in this area has been reported is not known to the best of our knowledge and hence the basis of the work.

\section{MATERIALS AND METHODS Collection of Samples and Fermentation Containers}

Sorghum bicolor and clay container were purchased at Nasarawa Gwong market whereas galvanised container was purchased from the tinker shade of that market within Jos metropolis.

\section{Preparation of Samples}

The substrate was soaked and washed in distilled water and then malted over a period of three days (Okoh, 1998). $10 \mathrm{~g}$ of the malted grains were measured and pounded using ceramic mortar and pestle, until a paste was obtained. The paste was then mixed in $100 \mathrm{ml}$ of distilled water to get 'cold suspension'; the control was treated in the same way, except that the grains were not malted.

\section{Fermentation Process}

Fermentation process was carried out by the method of Okoh (1998). Each complete fermentation protocol was split into four phases: cold suspension, hot suspension, wort, Pito or Burukutu from each of which $80 \mathrm{ml}$ aliquot was measured and stored in plastic sample bottle. The wort was allowed to stand for 30 minutes after which it was separated into upper and lower layers by decantation. Inoculation for 12 hours of the former gave Pito whereas the latter resulted in Burukutu.

\section{Sample Digestion}

From each of the dried samples of
Burukutu and Pito, $0.5 \mathrm{~g}$ was digested and eventually made up to $5 \mathrm{ml}$ with distilled water. Digestion mixture used contained concentrated trioxonitrate (v) acid and concentrated tetraoxochlorate (vii) acid in the ratio $6: 1 \mathrm{v} / \mathrm{v}$ respectively.

\section{Preparation of Working Standards}

From stock solutions of $\mathrm{Zn}$ and $\mathrm{Mn}$ each containing 1000 ppm, working standard solutions of 1, 2 and $5 \mathrm{ppm}$ were prepared by dilution.

\section{Analysis of $\mathrm{Zn}$ and $\mathrm{Mn}$}

$\mathrm{Zn}$ and $\mathrm{Mn}$ concentration in the samples was analysed using automated Atomic Absorption Spectrophotometer (AASHITACHI 180-80 Polarized Zee man Model).

\section{Statistical Analysis}

The student's t-test, at $95 \%$ level of significance was used to analyse the data obtained.

\section{RESULTS}

Table 1 gives the level of $\mathrm{Zn}$ contamination in Burukutu as a function of extent of fermentation. On average, increase over control values is $343 \%$ and $3259 \%$ $(\mathrm{P}<0.05)$ for metallic and clay containers respectively. Considering individual phases for metallic container, Burukutu and hot suspension have the highest, $788 \%$ and lowest, $148 \%$, increases over the control in that order which is somewhat similar as for clay container with values of $733 \%$ and $143 \%$ $(\mathrm{P}<0.05)$ respectively. The result in table 2 gives values for fermenting Pito. Compared to control, the average increase for metallic and clay container is $295 \%$ and $252 \%(\mathrm{P}<0.05)$ respectively. Considering individual phases using clay container, hot suspension and Pito have the least, $142 \%$ and highest, $459 \%$ increase over control $(\mathrm{p}<0.05)$ in that order.

Table 3 gives the results for $\mathrm{Mn}$ in Burukutu. When compared to the control, the mean increase is $1438 \%$ and $815 \%$ for clay and metallic containers $(\mathrm{P}<0.05)$ respectively. The increases ranged from $377 \%, 462 \%$, metallic and clay in wort to $815 \%, 1438 \%$, metallic and clay in Burukutu $(\mathrm{P}<0.05)$.Considering Pito in table 4, the average increase over the control is $1292 \%$ and $1150 \%$ for metallic and clay containers respectively. 
Table 1: Mean level of $\mathrm{Zn}$ for different phases of fermenting Burukutu (parts per million, ppm).

\begin{tabular}{|c|c|c|c|c|}
\hline \multirow[t]{2}{*}{ Phase of Fermentation } & \multicolumn{2}{|c|}{ Concentration of $\mathrm{Zn}(\mathrm{ppm})$} & \multicolumn{2}{|c|}{$\%$ increase over Control } \\
\hline & $\begin{array}{l}\text { Metallic } \\
\text { Container }\end{array}$ & $\begin{array}{l}\text { Clay } \\
\text { Container }\end{array}$ & $\begin{array}{c}\text { Metallic } \\
\text { Container }\end{array}$ & $\begin{array}{l}\text { Clay } \\
\text { Container }\end{array}$ \\
\hline Cold Suspension & $4.55 \pm 0.77$ & $4.37 \pm 0.90$ & 264 & $250(\mathrm{P}<0.05)$ \\
\hline Hot Suspension & $3.10 \pm 0.68$ & $3.04 \pm 1.28$ & 148 & $143(\mathrm{P}<0.05)$ \\
\hline Wort & $3.41 \pm 0.82$ & $3.44 \pm 1.92$ & 172 & $172(\mathrm{P}<0.05)$ \\
\hline Burukutu & $11.10 \pm 0.88$ & $10.41 \pm 0.98$ & 788 & $733(\mathrm{P}<0.05)$ \\
\hline Control & 1.25 & 1.24 & - & - \\
\hline
\end{tabular}

Table 2: Mean level of $\mathrm{Zn}$ for different phases of fermenting Pito (parts per million, ppm).

\begin{tabular}{|c|c|c|c|c|}
\hline \multirow[t]{2}{*}{ Phase of Fermentation } & \multicolumn{2}{|c|}{ Concentration of $\mathrm{Zn}$ (ppm) } & \multicolumn{2}{|c|}{$\%$ increase over Control } \\
\hline & $\begin{array}{c}\text { Metallic } \\
\text { Container }\end{array}$ & $\begin{array}{c}\text { Clay } \\
\text { Container }\end{array}$ & $\begin{array}{l}\text { Metallic } \\
\text { Container }\end{array}$ & $\begin{array}{c}\text { Clay } \\
\text { Container }\end{array}$ \\
\hline Cold Suspension & $4.5 \pm 0.98$ & $4.07 \pm 1.58$ & 266 & $230(\mathrm{P}<0.05)$ \\
\hline Hot Suspension & $3.50 \pm 1.60$ & $2.98 \pm 0.62$ & 185 & $142(\mathrm{P}<0.05)$ \\
\hline Wort & $3.41 \pm 0.78$ & $3.40 \pm 1.98$ & 177 & $177(\mathrm{P}<0.05)$ \\
\hline Pito & $8.03 \pm 0.72$ & $6.65 \pm 1.17$ & 553 & $459(\mathrm{p}<0.05)$ \\
\hline Control & 1.23 & 1.21 & - & - \\
\hline
\end{tabular}

Table 3: Mean Level of Mn for different phases of fermenting Burukutu (parts per million, ppm).

\begin{tabular}{|c|c|c|c|c|}
\hline \multirow[t]{2}{*}{ Phase of Fermentation } & \multicolumn{2}{|c|}{ Concentration of $\mathrm{Mn}(\mathrm{ppm})$} & \multicolumn{2}{|c|}{$\%$ increase over Control } \\
\hline & $\begin{array}{l}\text { Metallic } \\
\text { Container }\end{array}$ & $\begin{array}{c}\text { Clay } \\
\text { Container }\end{array}$ & $\begin{array}{c}\text { Metallic } \\
\text { Container }\end{array}$ & $\begin{array}{c}\text { Clay } \\
\text { Container }\end{array}$ \\
\hline Cold Suspension & $1.50 \pm 0.61$ & $1.57 \pm 0.5$ & 1054 & $1108(\mathrm{P}<0.05)$ \\
\hline Hot Suspension & $1.10 \pm 0.76$ & $1.24 \pm 0.94$ & 746 & $854(\mathrm{P}<0.05)$ \\
\hline Wort & $0.62 \pm 0.43$ & $0.73 \pm 0.66$ & 377 & $462(\mathrm{P}<0.05)$ \\
\hline Burukutu & $1.10 \pm 1.04$ & $2.01 \pm 0.98$ & 815 & $1438(\mathrm{P}<0.05)$ \\
\hline Control & 0.15 & 0.13 & - & - \\
\hline
\end{tabular}

Table 4: Mean level of Mn for different phases of fermenting Pito (parts per million, ppm).

\begin{tabular}{lccccc}
\hline Phase of Fermentation & \multicolumn{2}{c}{ Concentration of Mn $(\mathbf{p p m})$} & & \multicolumn{2}{c}{ \% increase over Control } \\
\cline { 2 - 3 } & $\begin{array}{c}\text { Metallic } \\
\text { Container }\end{array}$ & $\begin{array}{c}\text { Clay } \\
\text { Container }\end{array}$ & & $\begin{array}{c}\text { Metallic } \\
\text { Container }\end{array}$ & $\begin{array}{c}\text { Clay } \\
\text { Container }\end{array}$ \\
\hline Cold Suspension & $1.32 \pm 0.71$ & $1.40 \pm 0.82$ & & 843 & $1066(\mathrm{P}<0.05)$ \\
Hot Suspension & $1.01 \pm 0.98$ & $1.04 \pm 1.02$ & & 742 & $643(\mathrm{P}<0.05)$ \\
Wort & $0.51 \pm 0.33$ & $0.52 \pm 0.41$ & & 325 & $271(\mathrm{P}<0.05)$ \\
Pito & $1.67 \pm 0.83$ & $1.75 \pm 0.90$ & & 1292 & $1150(\mathrm{P}<0.05)$ \\
Control & 0.14 & 0.12 & & - & - \\
\hline \multicolumn{2}{c}{ Values are means \pm SD of three determinations. }
\end{tabular}


For the individual phases, the least and highest increases over control are the wort: 177\%; $177 \%$ and Pito: 553\%; $459 \%$ for metallic and clay containers in that order $(\mathrm{P}<0.05)$. From the results, the levels of the metals in each drink were higher than the levels in the controls; hence $\mathrm{Zn}$ and Mn could be seen to be contaminants of local native beers.

\section{DISCUSSION}

Virtually all metals are toxic if ingested in large enough quantities and the resultant toxicity or poisoning could be acute high dose exposure, intentionally, accidental or chronic low level exposure. They generally exert their toxicity by forming ligands with organic compounds and hence the resultant molecules loose their ability to function properly which leads to the malfunction or death of the affected cells; they also exert their effects by inhibiting certain enzyme systems. Okoye (2005) reported that sources of potential toxic chemicals in human foods and drinks include food utensils and packaging materials, food spoilage microbes, agrochemicals, industrial chemical wastes and domestic water.

Burukutu and Pito are fermented native drinks prepared using clay or metallic (alloys, iron, aluminium or galvanised) containers as fermentation vessels. These cooking vessels are constructed from unsuitable metal or metal alloys which easily get corroded by cooking water thus introducing trace elements such as $\mathrm{Zn}, \mathrm{Cu} \mathrm{Fe}$ into the beverage (Okoye, 1990; Gazuwa et al., 2006). Ubom and Okoye (1992) have reported a pH-dependent contamination of Burukutu by iron (Fe) and that the equilibrium favoured the leaching of iron into the beverage.

In its elemental form, zinc does not occur in the natural milieu and is therefore present in the divalent state, $\mathrm{Zn}^{2+}$. The range of normal plasma zinc level is from $85-110$ $\mu \mathrm{g} / \mathrm{dl}$, and the liver receives up to $40 \%$ of a dose whereas the prostate is reported to have the greatest deposit in the body (Razak, 2006); zinc doses $\geq 20 \mathrm{mg}$ have been reported to cause stomach upset, nausea, inhibition of intestinal alkaline phosphatase, xanthine oxidase, liver catalase, cytochrome oxidase, succinic dehydrogenase (Razak, 2006). Furthermore, high doses of this metal weaken immune function, lowers high density lipoprotein levels ("good" cholesterol), raises low density lipoprotein levels ("bad" cholesterol) thus enhancing the incidence of atherosclerosis (Razak, 2006).

Manganese exists in compounds in up to eight different valence states and the cationic species have been reported to be more toxic than its anionic species. It is implicated in causing decreased absorption of Fe and thus may lead to anaemia, inhibition of the $\mathrm{Cu}$ metalloenzymes, also linked to hepatitis and post hepatic cirrhosis, irreversible nervous system breakdown and blocks calcium channels and depletes dopamine which leads to Parkinson's disease (Internet Health Report, 2007).

Gazuwa et al. (2006) have reported iron (Fe) as contaminant of Pito and Burukutu and their $\mathrm{pH}$ values were 3.3 and 3.2 respectively. At this acidic $\mathrm{pH}$, the tendency is for these metals to undergo reduction to other salts or compounds or even the elemental form which could spark off lethal consequences. For instance, zinc has been shown to cause lethargy, anaemia, on chronic exposure, it damages the pancreas while oral zinc increases faecal excretion of copper and blocks the absorption of ingested minerals (Razak, 2006). Most reports of acute $\mathrm{Zn}$ toxicity are related to food poisoning incidents especially when stored in galvanized containers (Razak, 2006). The physiological requirement for $\mathrm{Zn}$ is between $10 \mathrm{mg}$ to $15 \mathrm{mg}$ per day and that for manganese is about 30 to $35 \mathrm{mg}$ per day.

It could be hypothesised that consumers of these drinks stand the risk of being exposed to continuous accumulation of zinc and manganese which may result in the toxic effects of these metals even though the body has its own defence mechanism against them including sequestration with metallothenein; formation of inclusion bodies and transforming them into their less toxic forms. It must be stated here that the vessels used in this work were purchased from the markets, these brewers however do recycle the containers and since repeated usage and therefore continuous heating tends to make especially soil much harder and stronger, the walls may not be easily leached into the drink as in the case of new clay vessels. Furthermore, all the samples were digested prior to analysis to ensure that organic 
components were burnt off and the metals reduced to elemental forms, failure of which may result in the metals forming complexes thus making the results unreliable. However, these drinks are not digested but consumed as soon as they are prepared and hence the levels reported in this article may not be the actual reflection of what obtains in reality. This does not however imply that there will be no leaching of the inner walls of brewing containers at all but that the magnitude of the leaching decreases with continuous usage which can not obliterate the fact that these metals could accumulate in the body over time which may become significant as to have adverse long term health consequences on the consumers.

\section{Conclusion}

From the results obtained, the drinks were contaminated with $\mathrm{Zn}$ and $\mathrm{Mn}$ because their levels are higher than that of the controls; of all the phases of fermentation, the levels of both metals are highest in Burukutu and Pito. Compared to control values, it appears as if contamination was due to the fermentation process itself, the container-type used or combination of the two. The extent of contamination with zinc appeared to be higher in metallic than in clay vessel for both drinks; in the case of manganese, converse was the case in Burukutu whereas its levels in Pito were similar in both types of vessels. Consumers could be exposed to $\mathrm{Zn}$ and $\mathrm{Mn}$ overload since metallic pots could be galvanized or alloys; the soil from which the pots were made could be rich in these metals as seen in the results obtained. This may complicate or be a risk factor to the aetiology of such disease conditions as liver cirrhosis, cancer, and hepatitis usually ascribed to alcoholism. Excessive exposure to these metals may be harmful even though some people may go for years with chronic metal accumulation without suffering illnesses(s); hence we cannot but postulate that nature may have conferred some adaptations on the inhabitants that keep the acute toxicity of these metals from manifesting among drinkers or some mechanisms are in place in the milieu that antagonise the toxic effects of these metals.

\section{REFERENCES}

Bennet DR, Baird CJ, Chan K, Crookes PF, Bremmer CG, Gottlieb MM, Narikotu W. 1997. Zinc Toxicity following Massive Coin Ingestion. American Journal of Medicine and Pathology, 18(2): 143-153.

Bhutta ZA, Black RE, Brown KH. 1999. Prevention of Diarrhoea and Pneumonia by Zinc Supplementation in Children in Developing Countries: Pooled Analysis of Randomised Controlled Trials. Zinc Investigators Collaborative Group. $J$ Paediatr., 135: 689-697.

Dawson ER, Alberts J, McGanity WJ. 1990. Serum Zinc Changes due to Iron supplementation in Teenage Pregnancy. AM. J. Clin. Nutr., 50: 848852.

Finley JW. 1999. Manganese Absorption and Retention by Young Women is Associated with Serum Ferritin Concentration. Am. J. Clin. Nutr., 70:3743.

Fosmire GJ. 1990. Zinc Toxicity. Am J. Clin Nutr., 51(2): 225-227

Gazuwa SY, Dabak JD, Ubom GA. 2006. Iron contamination of two local alcoholic drinks. Journal of Medicine in the Tropics, 8(1): 32-38.

Internet Health Report. 2007. Condition: Manganese toxicity. THE ANALYST ${ }^{\mathrm{TM}}$; $1-5$.

Krieger D, Krieger S, Jenson O. 1995. Manganese and chronic Hepatic Encephalopathy. Lancet., 346:270-274.

Macklin ML, Piedmonte M, Celandines C. 1998. Zinc Gluconate Lozenges for Treating Common Cold in Children. A randomised Controlled Trial". JAMA, 279:1962-1967.

Mossad SB, Macknin, ML, Medendorp SV. 1996. Zinc Gluconate Lozenges for Treating the Common Cold. Ann. Lat. Med., 125: 81-88.

Murray KR, Grammer DK, Mayes PA, Rodwell VW. 1992. Harpers Biochemistry (24th edn). Appleton and Lange Standfold Connecticut.

Obasi OE, Ogbadu GH, Ukoha AI. 1987. Aflatoxins in Burukutu (Local Beer). Trans. Roy. Soc. Trop. Med. Hyg., 81: 879. 
Okoh PN. 1998. Cereal grains. In Nutritional Quality of Plant Foods: Post Harvest Publication: Benin. 32-52.

Okoye ZSC, Ekpenyong KI. 1984. Aflatoxin $\mathrm{B}_{1}$ in Native Beer brewed in Jos Suburbs. Trans. Roy. Soc. Trop. Med. Hyg, 78: 417-478.

Okoye ZSC.1990. Chemical Food Poisoning: Causes, Control and Prevention. Postgraduate Open Lecture, University of Jos: Nigeria.

Okoye ZSC.1992. Biochemical Aspects of Nutrition ( ${ }^{\text {st }}$ edn). New Delhi-110001; 16.

Okoye ZSC. 2005. Food chemical poisons: not by enemy alone. Inaugural Lecture, Series 20, University of Jos, pp 7-15.
Razak L. 2006. The Abuse and Toxicity of Zinc. National Poison Centre, Universiti Sains: Malaysia Penang.1-2.

Sandstead HH, 1995. Requirement and Toxicity of Essential Trace Elements Illustrated by Zinc and Copper. AM. J. Clin. Nutr., 61(suppl): 215-245.

Spencer H, Norris C, Williams, D. 1994. Inhibitory Effects of Zinc on Magnesium Balance and Magnesium Absorption in Man. J. AM. Coll. Nutr., 13: 479-484.

Ubom GA, Okoye ZSC. 1992. The Relationship between Trace Metal contents in Native Cereal Beer and the Incidence of Liver Cirrhosis in Jos, Nigeria. Bioscience Research Communications., 42: 1-8. 